\title{
The Impact Of Accounting Scandals On Accounting Students
}

\author{
Steven R. Jackson, (E-mail: sjackson@utm.edu), Loyola University of New Orleans
}

\begin{abstract}
At no other time in the history of the accounting profession has there been such an impact to the financial reporting function within the capital market structure. The institutions responsible for the financial reporting function are reeling from the fallout of these financial-reporting scandals. "Reports on the collapse of Enron, the bankruptcy of WorldCom, and a growing list of failures and near failures have exposed massive manipulations of financial reporting by management, inexplicable breakdowns in the independent audit process, astonishing revelations of holes in our financial-reporting standards and practices, and studding lapses of corporate governance". (Sutton, 2002). As Sutton also points out, in this environment, investors and the public have become increasingly skeptical about a system that seems to be out of control. The impact on perceptions of the investing public must also include students studying business and more specifically students studying accounting. This study uses a questionnaire developed by Gramling, et.al. (1996) to study the perceptions of auditing students before and after the above mentioned financial-reporting scandals. Students in two auditing classes, one before the scandals and one after, were given the questionnaire at the beginning of their auditing course. The results show a significant change in student perceptions concerning audit expectation issues after the scandals, but before they studied auditing.
\end{abstract}

\section{Introduction}

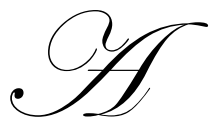

$\mathrm{t}$ no other time in the history of the accounting profession has there been such an impact to the financial reporting function within the capital market structure. In the past the profession has experienced scandals and faced questions about the auditing profession but the media coverage of these events was less intense than the coverage today. Potential and current accounting students and their parents have greater access to information concerning the current accounting scandals which increases the potential impact on decisions concerning careers.

As far back as the 1960s financial scandals raised questions about the performance of auditors. The number and size of lawsuits increased during the 1960s. Those cases which resulted in huge losses and raised auditor performance questions, included Westec (1965), National Student Marketing (1969), Penn Central and Four Seasons Nursing Centers (1970). In 1967 John L. Carey said that "the accounting profession is going through a most unusual and difficult period. On some days it seems as though we were being attacked from all sides." He was concerned over "a feeling that CPAs are not quite the stalwart protectors of investors and creditors that the public had assumed they were" (Carey, 1967, 15). These same concerns are being expressed today.

In 1972, the Stirling Homes bankruptcy followed by Equity Funding in 1973 had a major impact on the accounting profession. Once again the credibility of auditors was questioned. These failures plus other problems caused the first broad attack by Congress against the profession. Senators Moss and Metcalf, in separate reports, questioned the independence of the Big Eight firms from their clients. Both these reports recommended that the federal government set accounting and auditing standards for publicly traded corporations. However, no legislation was passed. This led the AICPA to create the Division of CPA Firms and the Public Oversight Board (POB). 
In the 1980s the amount of nonaudit services offered by some independent public accountants, the growth of MAS services and the contribution of those practice areas to profits caused concerns about independence, objectivity and professionalism in the profession. In 1979, the POB said in a major study:

There is enough concern about the scope of services in responsible quarters so that the question cannot be dismissed as a "nonproblem." The board believes that there is potential danger to the public interest and to the profession in the unlimited expansion of MAS to clients, and some moderating principles and procedures are needed. (Public Oversight Board 1979, 56)

Also in 1980 at the annual AICPA meeting William R. Gregory warned members of the increasingly fractious climate in the profession:

It seems that the effects of the phenomenal growth in the profession and competitive pressures have created in some CPAs attitudes that are intensely commercial and nearly devoid of the high-principled conduct that we have come to expect of a true professional. It is sad that we seem to have become a breed of highly skilled technicians and businessmen, but have subordinated courtesy, mutual respect, self-restraint, and fairness for a quest for firm growth and a preoccupation with the bottom line.

During the 1980s, the cases of auditor fraud were very embarrassing to the profession. These cases-ESM Government Securities, Wedtech Corp. and ZZZZ Best raised questions about the propriety of accounting and auditing.

Mark Stevens in his book, The Big Six, wrote:

As the firms become more intimately involved with their clients through their consulting practices, as they think of themselves more and more as consultants who happen to do audits just to get a foot in the door and as they continue to reward salesmanship and marketing over technical proficiency, they are clearly headed toward a day of reckoning---a day when the firms, or Congress acting for them, will force the issue and demand that they decide whether they want to retain the licensed privilege of auditing the corporate community by spinning off the MAS practices, or whether they want to join in the open competition of management consulting by ejecting the audit practices. (Stevens 1991, 250-251)

During the 1990s, the big firms expanded into global, multidisciplinary, professional services firms that also happened to conduct audits. In June 1996 Arthur Levit, then SEC Chairman, said "I'm deeply concerned that 'independence' and 'objectivity' are increasingly regarded by some [in the accounting profession] as quaint notions.... caution the [accounting] industry, if I may borrow a Biblical phrase, not to 'gain the whole world, and lose [its] own soul"' (Levit 1996).

All of these problems and warnings came at a time when media coverage was not as extensive and thus the general public, the population not directly involved in financial services, were not as aware of the problems. Today these events would receive much more media coverage such as what happened with Enron and WorldCom and others.

The institutions responsible for the financial reporting function are reeling from the fallout of these financial-reporting scandals. "Reports on the collapse of Enron, the bankruptcy of WorldCom, and a growing list of failures and near failures have exposed massive manipulations of financial reporting by management, inexplicable breakdowns in the independent audit process, astonishing revelations of holes in our financial-reporting standards and practices, and studding lapses of corporate governance". (Sutton, 2002). As Sutton also points out, in this environment, investors and the public have become increasingly skeptical about a system that seems to be out of control. 
This impact on perceptions of the investing public must also include students studying business and more specifically students studying accounting. Sutton points out that we must confront some challenging questions in light of the failures mentioned above. These questions are:

- Can we believe in and rely on the independent audit?

- Can we believe that our accounting and disclosure standards provide the transparency that is essential to investors and the public?

- $\quad$ Can we rely on self-regulatory systems to ensure audit quality and to root out and discipline substandard performance?

- $\quad$ Can we rely on corporate governance processes---oversight by boards of directors and audit committees--to ride herd on management and to see to it that auditors do their job?

Sutton goes on to say that events have changed how we look at and think about those questions, and that the change may last for decades to come. These questions concerning how we deal with and potentially change a system that seems flawed certainly impact the students presently majoring in accounting or thinking about accounting as a field of study.

The remainder of this paper is outlined as follows. The second section reviews the relevant literature. The third section describes the survey instrument used to obtain the empirical evidence and provides information on the survey respondents. The fourth section presents the analysis of the survey responses. The final section concludes with summary comments and suggestions for future research in this area.

\section{Literature Review}

Student decisions pertaining to majoring in accounting are impacted by the perceptions these students have of the accounting profession. Students may choose accounting as a major right out of high school or may make the choice after starting college. A number of factors such as job availability, starting pay, potential for advancement and the impressions of what the career will provide, impact the decisions of students to become or remain accounting majors.

Many accounting programs have faced declining enrollments in the last few years even while those same accounting programs have updated curricula and increased efforts to recruit students. Barsky et al. (2003) points out that accounting programs cannot control important external issues that arise in today's dynamic business marketplace. This study looks at one aspect of this business marketplace, specifically the impact of recent accounting scandals and the impact of those scandals on the perceptions of the students about the profession.

Barsky et al. (2003) states that many students and their parents simply do not understand how dramatically the role of accountants and their education has changed during the past decade (Barsky and Catanach 2001). Few realize that the accountant's role has evolved from that of financial accounting and tax advisor to one of consultant who offers advice on a variety of management issues, including performance improvement, human resource systems, and other financial matters (IMA 1999). In fact, a recent Harris poll (2001) on the "prestige of professions" rated accountants $16^{\text {th }}$ out of 17 listed professions. The accounting scandals project the image that accounting may no longer be such a stable profession. The related risk of legal liability, criminal prosecution and pressure for unethical behavior also may dampen student interest in accounting (Barsky, et al. 2003).

In a 1996 study, Gramling et al. presented results of a survey questionnaire used to ascertain whether the perceptions of undergraduate business students about audit expectation issues would be changed after completion of an undergraduate auditing course. They also compared the perceptions of students subsequent to completion of an auditing course to the perceptions of professional auditors. The issues addressed in their study include: the appropriate role for auditors; the specific parties to whom auditors should be responsible; the prohibitions and regulations that should be placed on audit firms; and the decisions that auditors would likely make in a series of specific case studies. The survey results were also used to provide evidence as to the perceptions of these three 
groups regarding key performance attributes of auditing. This study will use the same questionnaire to study the perceptions of students before and after the accounting scandals.

It has long been accepted that there exists an expectations gap between auditors and users of financial statements regarding the value of the audit function. The expectations gap is defined as "the difference between what the public and financial statement users believe auditors are responsible for and what auditors themselves believe their responsibilities are" (AICPA 1993).

In the United States, auditing standards have been issued as an attempt to reduce the expectations gap (Guy and Sullivan 1988). In general, the research which has been conducted to date tends to focus on one or two expectation gap issues, and only from the perspective of one of the relevant parties.

\section{The Survey Instrument}

The survey instrument was based on an instrument developed, tested, and used in a study of the audit expectations gap in Britain (Humphrey et al. 1993). Modifications were made by Gramling et.al. In recognition of differences in auditing and accounting issues between Britain and the United States. The instrument was not modified in the present study. The survey instrument consists of four primary sections: (1) a set of questions designed to elicit opinions on the role and nature of auditing; (2) a set of questions used to identify the attributes that subjects associate with aspects of auditor performance; (3) a series of short case studies used to determine actions that participants perceive auditors would take in a variety of circumstances; and (4) a set of questions designed to obtain biographical information and personality variables about the respondents.

The set of questions on the role and nature of auditing primarily comprises statements regarding existing and possible audit roles, prohibitions and regulations in the audit environment, and parties to whom auditors should be responsible. For each of the statements in this set, respondents were asked to indicate their extent of agreement of disagreement with the statement on a seven-point scale (1=Strongly disagree; $4=$ Neutral; $7=$ Strongly agree).

The set of questions used to identify aspects of auditor performance consists of a semantic differential testing instrument requiring respondents to assess the performance of auditors on various attributes of auditing. Although semantic differential instruments usually allow only for bi-polar responses, respondents to the survey reply on a 7 point Likert scale as to how successful they perceive auditors are at various activities (1= Extremely unsuccessful; 4=Neither successful or unsuccessful; 7=Extremely successful). For this set of questions, respondents could also indicate that the activity was not applicable to auditors.

The short cases provide a total of nine responses. Two responses refer to possible audit report qualifications; two refer to potential whistle-blowing situations; one refers to a potential resignation situation; and four refer to the level of work that an auditor would be expected to complete. While beginning auditing students may be less familiar with the situations in the cases, their perceptions are important if the two groups differ.

The first auditing class surveyed was in the spring semester of 2001 and the second auditing class was in the fall of 2003. Both classes completed the questionnaires the first day of class so the impact of the subsequent auditing class was removed from consideration. The first class consisted of 12 students and the second class had 23 students.

\section{Discussion of Results}

The results were analyzed using $\mathrm{z}$ tests to measure differences between means of the two groups of unequal size. Table one shows the results of the section of the questionnaire dealing with respondents views about auditors and the auditing process. One question in that section showed a significant difference between the two groups. The students before the scandals were neutral on the statement that "audit committees comprising non-executive directors should improve auditor independence" and students after the event were moderately in agreement. This 
seems to indicate that the student's perception of the function of audit committees changed in favor of including non-executive directors.

Table 1: Views about Auditors and the Auditing Process

\begin{tabular}{lccc}
\hline Statement & $\begin{array}{l}\text { Students } \\
\text { Pre-Event }\end{array}$ & $\begin{array}{l}\text { Students } \\
\text { Post-Event }\end{array}$ & $\begin{array}{l}\text { Z Value } \\
\text { (p-value) }\end{array}$ \\
\hline $\begin{array}{l}\text { Audit Committees comprising } \\
\begin{array}{l}\text { Non-executive directors should } \\
\text { Improve auditor independence }\end{array}\end{array}$ & & & \\
& 4 & 4.91 & -2.06245 \\
& & & $(.01)$
\end{tabular}

$1=$ Strongly disagree; $4=$ Neutral; 7 = Strongly Agree

Table two shows the results of the section of the questionnaire dealing with the respondents views about possible prohibitions and regulations on an audit firm. In this section five questions showed significant differences between the two groups.

Table 2: Views about Possible Prohibitions and Regulations on an Audit Firm

$\left.\begin{array}{llll}\hline \text { Statement } & \begin{array}{l}\text { Students } \\ \text { Pre-Event }\end{array} & \begin{array}{l}\text { Students } \\ \text { Post-Event }\end{array} & \begin{array}{l}\text { Z-Value } \\ \text { (p-value) }\end{array} \\ \hline \text { An Audit Firm Should: } & & & -3.51063 \\ \text { not provide MAS to its audit clients } & 3.167 & 4.91 & (.0002) \\ & & 4.78 & -1.34701 \\ \text { not act primarily to make a profit } & 3.83 & & (.088)\end{array}\right)$

Post-event students were strongly in favor of audit firms not providing consulting services (MAS) to its audit clients, where pre-event students slightly disagreed with that statement. This is one of the issues that were heavily covered in the media after the Enron and WorldCom failures and these results reflect the increased awareness of students and the public regarding this perceived conflict of interest. These same students were also in favor of audit firms not being primarily concerned with making a profit which was also an issue discussed in the media. The last two questions in this section reflect the student's neutral attitude toward someone independent of the firm setting the audit fees and also the attitude toward legal liability. Most students at the beginning of an audit course may not be as familiar with proportionate and joint and several liability as practicing CPA's so the responses to this question should not be surprising. 
Table three contains the results of the group of questions dealing with views about how successful auditors are at selected activities.

Table 3: Views About How Successful Auditors Are At Particular Activities

\begin{tabular}{|c|c|c|c|}
\hline Statement & $\begin{array}{l}\text { Students } \\
\text { Pre-Event }\end{array}$ & $\begin{array}{l}\text { Students } \\
\text { Post-Event }\end{array}$ & $\begin{array}{l}\text { Z-score } \\
\text { (p-value) }\end{array}$ \\
\hline Prescribing remedies to problems & 4.55 & 5.22 & $\begin{array}{l}-.43697 \\
(.075)\end{array}$ \\
\hline Making a profit & 5.58 & 6.07 & $\begin{array}{l}-1.305 \\
(.095)\end{array}$ \\
\hline $\begin{array}{l}\text { Preventing errors and } \\
\text { Irregularities }\end{array}$ & 3.58 & .91 & $\begin{array}{l}-2.64043 \\
(.004)\end{array}$ \\
\hline $\begin{array}{l}\text { Acting independently without } \\
\text { regard to self-interest }\end{array}$ & 5.42 & 4.61 & $\begin{array}{l}1.766715 \\
(.036)\end{array}$ \\
\hline $\begin{array}{l}\text { Being even-handed with the } \\
\text { interests of others }\end{array}$ & 6 & 5.30 & $\begin{array}{l}1.701947 \\
(.044)\end{array}$ \\
\hline
\end{tabular}

Students post Enron/WorldCom, were a little bit more optimistic about the ability of auditors to solve problems and also make a profit. It is interesting that the post event students were significantly more comfortable with auditors preventing errors and irregularities when that inability was at the core of the failures. These post event students were less in agreement with auditors acting independently and being even-handed with the interest of others. Those responses are more in line with what would be expected given the level of media coverage of those topics.

\section{Discussion}

What can we, as accounting educators, do to try and overcome this negative media coverage of the profession and to reverse the enrollment trends? By increasing our discussion of our Professional Code of Ethics with prospective students and their parents and show them that there is much more to the practice of public accounting than just auditing we can begin to reverse the trends. We need to emphasize the forensic aspects of fraud investigation, the consulting needs and opportunities available with an accounting degree. Prospective students should also be aware of the value of the accounting degree in other areas of business. An accounting degree is very useful and valuable to other career paths.

Schools and departments need to revise recruiting brochures used at the high school level to better inform potential accounting majors of the true state of the profession and what being an accountant really means. Another group of potential new accounting majors are business students who have not chosen a major or who are considering a change. These students are exposed to accounting in the first two accounting courses taught at most business schools. As recommended by the Accounting Education Change Commission these two courses are the most important in attracting and retaining accounting majors. The best instructors need to be in these two courses and the subject matter should be from the user approach. These courses are an excellent venue for presenting the accounting profession in a positive light to retain and attract accounting majors.

These small changes are only a small step in overcoming a negative image associated with our profession. There is much more that we as accounting educators can do to enhance the experience of our students as they prepare for entry into the profession. 


\section{Summary}

Overall these results would seem to indicate that students exposed to media coverage of these events which had a negative impact on public perceptions of the auditing profession were inclined to think that consulting services should be independent of auditing services and firms should be less concerned with making a profit and more concerned with providing service to clients and the investing public. These results may provide some insight into the decreasing popularity of accounting as a career choice among young people today.

More research needs to be done in this area to measure the impact of the auditing course on these perceptions and how we as accounting educators might overcome the negative perception of the profession to attract the best and brightest students to major in accounting.

This study looks at a very small sample of students and may not have validity outside those groups studied. The students were in two different regions of the country which may have an impact on the perceptions of the students. The impact of the audit professor and textbook should have no impact on the responses because the questionnaire was administered at the beginning of each semester however; the other accounting coursework taken preceding the audit class may have impacted the responses. It would be difficult to imagine a situation where these two cases were not discussed in other accounting classes and the perceptions of accounting faculty passed to the students.

These threats aside these results indicate a change in perception of accounting students in today's environment that should be considered when recruiting and retaining accounting majors.

\section{References}

1. AICPA. 1993. The expectations gap standards: Progress, implementation issues, research opportunities. Proceedings of the Expectations Gap Roundtable in Charleston, SC (May 11-12, 1993). New York: AICPA

2. Barsky, N.P., and A.H. Catanach, Jr. 2001. Perception is Reality: Managing Student and Parental Expectations is Critical to Increasing Accounting Enrollments. Management Accounting Quarterly (Fall): 22-32.

3. Barsky, N.P., Catanach, A.H., and B. M. Kozlowski. Creating Strategic Responses to Critical Risks Facing Accounting Education. Workpaper presented at the AAA annual meeting, 2003.

4. Gramling, A.A., J.W. Schatzberg, and W.A. Wallace, 1996. The role of undergraduate auditing coursework in reducing the expectations gap. Issues in Accounting Education 11 (1): 131-161.

5. Guy, D.M., and J.D. Sullivan. 1988. The expectations gap auditing standards. Journal of Accountancy (April): 36-46.

6. Harris Poll. 2001. Number 50: Doctors Seen As Most Prestigious of Seventeen Professions and Occupations, Followed by Scientists (\#2), Teacher (\#3), Clergy (\#4), and Military Officers (\#5). Harris Interactive (October 10).

7. Humphrey, C., P. Moizer, and S. Turley. 1993. The audit expectations gap in Britain: An empirical investigation. Accounting and Business Research (Winter): 395-411.

8. Institute of Management Accountants (IMA). 1999. Counting More, Counting Less: Transformations in the Management Accounting Profession. Montvale, NJ.

9. Sutton. M.H. 2002. Financial Reporting at a Crossroads. Accounting Horizons (December): 319-328. 
Notes 